\title{
Respiratory medicine in Saskatchewan: An historical perspective
}

\author{
Donald W Cockcroft MD FRCPC
}

DW Cockcroft. Respiratory medicine in Saskatchewan: An historical perspective. Can Respir J 2015;22(4):197-198.

\section{EARLY DAYS: 1905 to 1957}

Saskatchewan (capital Regina) was created out of the Northwest Territories September 1, 1905, at the same time as Alberta, the second last provinces admitted to confederation. Its population has been relatively stable (one million $\pm 15 \%$ ) since 1930 . The University of Saskatchewan (U of S) was granted a provincial charter April 3, 1907, and, after considerable debate and controversy, Saskatoon was selected as the U of S site April 7, 1909. In 1912, the first building was opened and the first degree was awarded. A two-year preclinical school of medical sciences (total faculty of five for many years) opened in 1926, initially with classes in converted greenhouses (1); clinical years were completed elsewhere. A university teaching hospital was conceived in 1911 (1), excavation began in 1948; the cornerstone was laid September 19, 1952, by Tommy Douglas and the University Hospital (UH) opened May 14, 1955. The first class of MDs fully trained at the $\mathrm{U}$ of $\mathrm{S}$ graduated in 1957 . The $\mathrm{UH}$ was renamed the Royal University Hospital (RUH) in 1990 (2).

RESPIRATORY MEDICINE IN SASKATCHEWAN (1970s) The Saskatchewan Anti-Tuberculosis League, founded in 1911, unofficially known as the Saskatchewan Lung Association (SLA) from the 1960s and officially so renamed in 1987 (renamed the Lung Association of Saskatchewan in 2002) was responsible for many firsts in the diagnosis and management of TB; this history is detailed elsewhere (3). The first (nonphthisiologist) respirologist recruited to the Department of Medicine was Clive Deutcher in 1972; he left the university in 1976. In 1973, an agreement was signed between the League, the $\mathrm{U}$ of $\mathrm{S}$ and the $\mathrm{UH}$ to establish a respiratory disease unit in Saskatoon. The Ferguson Professorship, named after George Ferguson (superintendent of TB medical services, 1917 to 1948) was created and the first recipient was Jim Dosman, who joined the Division in July 1975; the pulmonary research laboratory at $\mathrm{UH}$, dedicated to the memory of George Ferguson, was opened in November 1975. Brian Graham, biomedical engineer, was recruited in April 1976 and, with assistance of the League, David Cotton joined the Division July 1976. July 1977 witnessed the arrival of Vern Hoeppner and Don Cockcroft, both applicants for the single position to replace Clive Deutcher, both recruited with the help of the League. Remarkably, all five members recruited over that 24-month period remained active at the university 37 years later (mid-2014). All four clinicians have been the Division Head, all four have held the Ferguson Professorship, and three of the four have been the Head of the Department of Medicine.

Despite major teaching and clinical demands, this small group proved to be very productive. Jim Dosman pioneered studies of respiratory disease in agricultural workers (4-6) and, in 1986, founded what is now the Canadian Centre for Health and Safety in Agriculture (CCHSA), a separate division within the Department of Medicine. David Cotton and Brian Graham studied gas exchange and measurement of diffusing capacity measurement (7-9), leading to the development of a three-equation (inspiration, breath-hold and expiration) method to more accurately calculate the diffusing capacity (8). Vern Hoeppner showed that high-pressure nocturnal ventilation was therapeutic rather than just supportive in respiratory failure due to kyphoscoliosis (10) and published work in TB $(11,12)$ including validation of directly observed TB therapy. Don Cockcroft followed up on the observation that allergen challenge increased airway responsiveness to histamine and methacholine (13), and studied the effect of common asthma drugs on this important feature (14). While studying the development of tolerance to the bronchoprotective effect of inhaled beta 2 -agonists, he made the reproducible observation that regular use of these agents caused significant increase in the airway response to inhaled allergen (15), a plausible explanation for beta agonist-induced worsened asthma control (16).

\section{RESPIRATORY MEDICINE IN SASKATCHEWAN: 1980 TO 2014}

In the years following the 1970s, our division has thrived and expanded, developing expertise in chronic obstructive pulmonary disease and exercise physiology (Darcy Marciniuk, Charlie Gallagher), sleep (David Cotton, Irv Mayers, Mike Fitzpatrick, Anil Nagpal, Brian McNab, John Reid, Rob Skomro, John Gjevre, Mark Fenton), lung transplantation (Mark Fenton), critical care (Irv Mayers, Karen Laframboise, John Gjevre), pulmonary hypertension (Karen Laframboise), interventional bronchoscopy (Chris Hergott) health economics (Erika Penz), basic immunology and allergy (John Gordon), health services research and the social dimensions of respiratory health (Donna Goodridge) and clinical laboratory features of asthma (Beth Davis). A clinical respiratory training program was started in 1983 and has trained 39 respirologists, 13 of whom are currently working in Saskatchewan (11 in respirology and two in general internal medicine) and six others who worked in the province for a time (four as academic division members). The division of Respirology, Critical Care and Sleep Medicine currently consists of eight university-based clinicians, five university-based nonclinicians (two emeritus) and 13 community-based clinicians, seven in Saskatoon and six in Regina, along with one Emeritus clinician in the CCHSA; this totals 22 clinical respirologists in the province.

The division has also been active nationally and internationally. The Division claims four past Presidents of the Canadian Thoracic Society (CTS), and one past President of the American College of Chest Physicians and is involved nationally in the CTS clinical assemblies, and internationally at various levels with the ACCP, the American Thoracic Society, the European Respiratory Society, the Forum of International Respiratory Societies and the American Academy of Allergy Asthma, and Clinical Immunology.

ACKNOWLEDGEMENTS: The author thanks Jacquie Bramley for assistance with preparation of the manuscript.

The full-length article can be viewed at the Journal's website at www.pulsus.com 


\section{REFERENCES}

1. Buchan DJ. Greenhouse to Medical Centre: Saskatchewan's Medical School 1926-78. Saskatoon: University of Saskatchewan, College of Medicine, 1983.

2. Horlick L. They Built Better Than They Knew: Saskatchewan's Royal University Hospital A History: 1955-1992. Saskatoon: Royal University Hospital Foundation and Saskatoon Health Board, 2001.

3. Larmour JBD. A The 75 year history of the Saskatchewan AntiTuberculosis League and the Saskatchewan Lung Association. Saskatoon: Saskatchewan Lung Association.

4. Cotton DJ, Graham BL, Li KY, Froh F, Barnett GD, Dosman JA. Effects of smoking and occupational exposure on peripheral airway function in young cereal grain workers. Am Rev Respir Dis 1982;126:660-5.

5. Dosman JA, Cotton DJ, Graham BL, et al. Sensitivity and specificity of early diagnostic tests of lung function in smokers. Chest 1981;79:6-11.

6. Dosman JA, Graham BL, Hall D, et al. Respiratory symptoms and alterations in pulmonary function tests in swine producers in Saskatchewan: Results of a survey of farmers. J Occup Med 1988;30:715-20.

7. Graham BL, Dosman JA, Cotton DJ. A theoretical analysis of the single breath diffusing capacity for carbon monoxide. IEEE Trans Biomed Eng 1980;27:221-7.

8. Graham BL, Mink JT, Cotton DJ. Implementing the three-equation method of measuring single breath carbon monoxide diffusing capacity. Can Respir J 1996;3:247-57.
9. Graham BL, Mink JT, Cotton DJ. Improved accuracy and precision of single-breath CO diffusing capacity measurements. J Appl Physiol Respir Environ Exerc Physiol 1981;51:1306-13.

10. Hoeppner VH, Cockcroft DW, Dosman JA, Cotton DJ. Nighttime ventilation improves respiratory failure in secondary kyphoscoliosis. Am Rev Respir Dis 1984;129:240-3.

11. Wobeser W, To T, Hoeppner VH. The outcome of chemoprophylaxis on tuberculosis prevention in the Canadian Plains Indian. Clin Invest Med 1989;12:149-53.

12. Pepperell C, Hoeppner VH, Lipatov M, Wobeser W, Schoolnik GK, Feldman MW. Bacterial genetic signatures of human social phenomena among M. tuberculosis from an Aboriginal Canadian population. Mol Biol Evol 2010;27:427-49.

13. Cockcroft DW, Ruffin RE, Dolovich J, Hargreave FE. Allergeninduced increase in non-allergic bronchial reactivity. Clin Allergy 1977;7:503-13.

14. Cockcroft DW, Murdock KY. Comparative effects of inhaled salbutamol, sodium cromoglycate, and beclomethasone dipropionate on allergen-induced early asthmatic responses, late asthmatic responses, and increased bronchial responsiveness to histamine. J Allergy Clin Immunol 1987;79:734-40.

15. Cockcroft DW, McParland CP, Britto SA, Swystun VA, Rutherford BC. Regular inhaled salbutamol and airway responsiveness to allergen. Lancet 1993;342:833-7.

16. Sears MR, Taylor DR, Print CG, et al. Regular inhaled beta-agonist treatment in bronchial asthma. Lancet 1990;336:1391-6. 


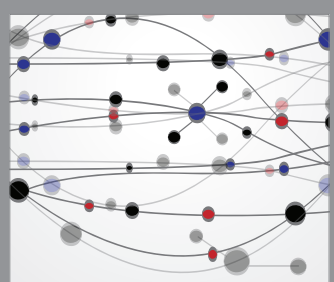

The Scientific World Journal
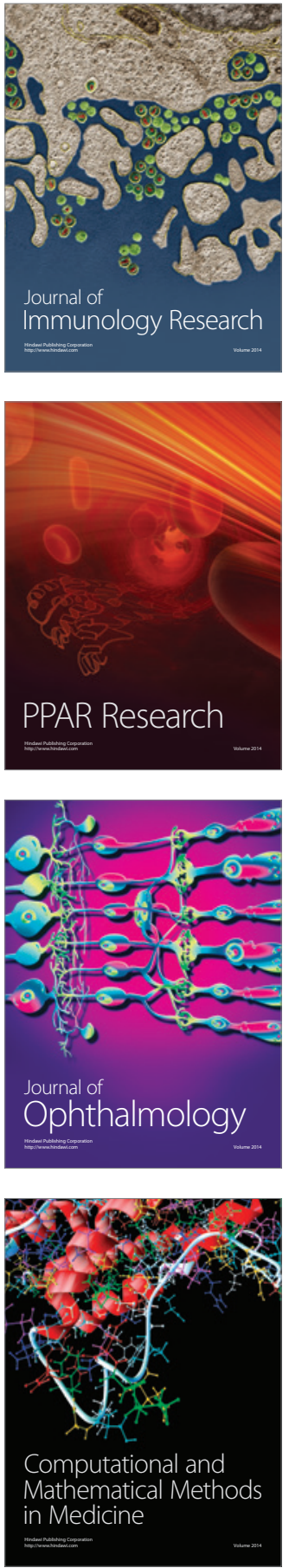

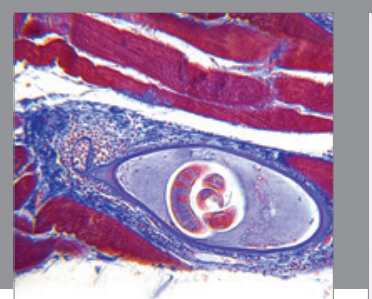

Gastroenterology Research and Practice

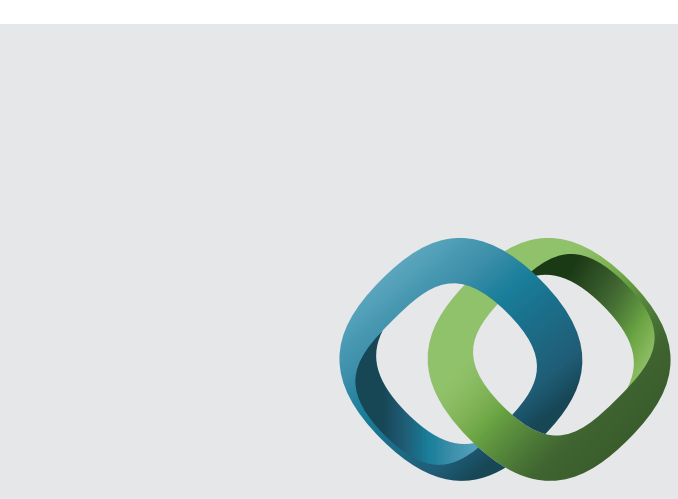

\section{Hindawi}

Submit your manuscripts at

http://www.hindawi.com
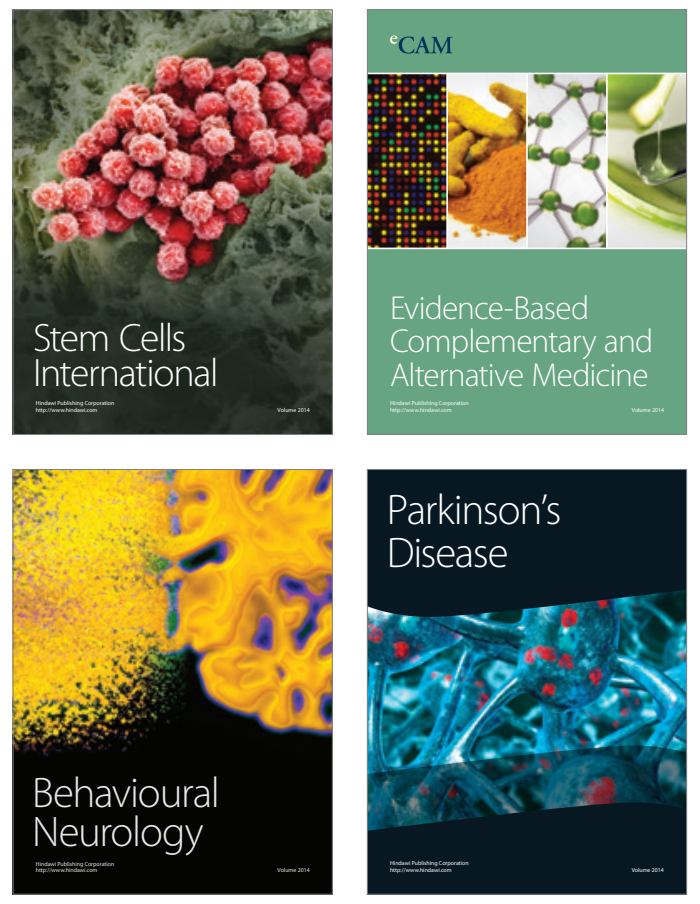
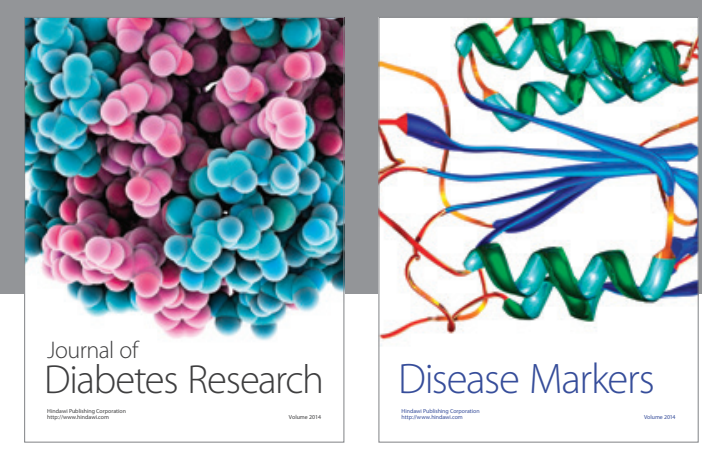

Disease Markers
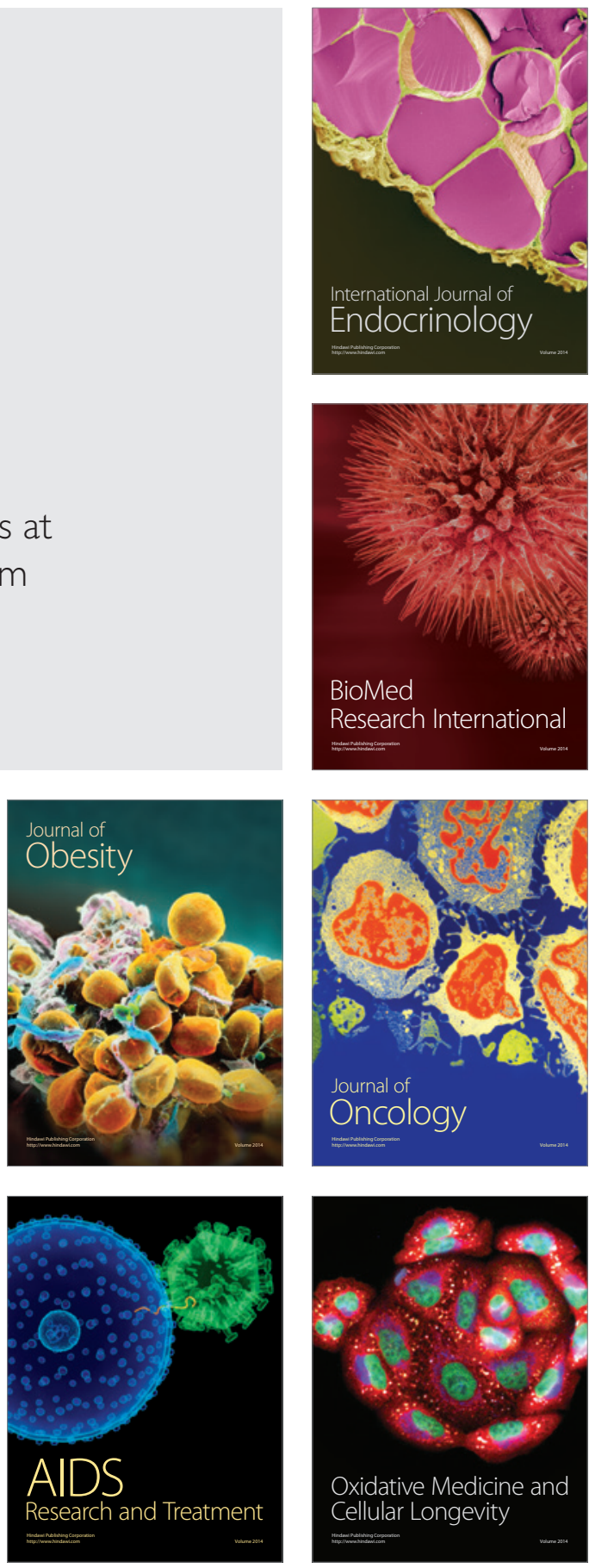